\title{
The Use of the Concept of "Language Variation" As a Stylistic Device in Pygmalion: Toward A Socio-Stylistic Approach
}

\author{
Dr. Adil Mohammed Hamoud Qadha ${ }^{1}$ \\ ${ }^{1}$ Department of English, College of Science and Arts, Blaqarn, University of Bisha, Bisha 61922, Saudi Arabia; \\ Hodeidah University, Yemen \\ Correspondence: Adil Mohammed Hamoud Qadha, Assistant Professor of Applied Linguistics, Department of \\ English, College of Science and Arts, Blaqarn, University of Bisha, Bisha 61922, Saudi Arabia; Hodeidah \\ University, Yemen. E-mail: amhmoood@ub.edu.sa or adel75q@yahoo.com
}

$\begin{array}{lc}\text { Received: August 7,2018 } & \text { Accepted: August 21, } 2019 \quad \text { Online Published: September 15, } 2019 \\ \text { doi:10.5539/ijel.v9n5p422 } & \text { URL: https://doi.org/10.5539/ijel.v9n5p422 }\end{array}$

\begin{abstract}
In this paper, the author supports the claim that there is an inevitable relationship between language and social class to which a speaker (character) belongs. The paper claims that literary language is a manifestation of the verbal practices done by real speakers in real communicative situations. The paper illustrates that Bernard Shaw in Pygmalion used the concept of "language variation" as a stylistic device to reveal some significant social aspects of Eliza Doolittle, the main character of the play. Drawing on Basil Bernstein's distinction between elaborated code and restricted code, the paper compares between Eliza as a low -class illiterate speaker and the same Eliza after having intensive linguistic training by Prof. Higgins. The analysis is based on some selected extracts of Eliza's speech in different conversational scenes in the play. The paper hypothizes that literary discourse, mainly dialogues, can be treated as an ordinary language used in real conversational situations. The analysis was conducted from phonological, syntactic, pragmatic and sociolinguistic perspectives.
\end{abstract}

Keywords: restricted code, elaborated code, illocutionary act, language variation, social class, interlocutor

\section{Introduction}

It is needless to say that the role of speech in the linguistic analysis of literary texts cannot be denied (C.f Page, 1973) and that no stylistic analysis can be fulfilled without taking speech or character talk as the main source of data to be studied and analyzed. This paper attempts to give a clear idea about the role of speech in the analysis of literary texts from linguistic perspectives. Thus, the main problem to be investigated in this paper is to show how speech plays a dominant role in determining the type of linguistic behavior of the speaker (character). In addition, the paper attempts to prove that the linguistic behavior of the speaker (character) reveals many social aspects of him/her. The importance of this study comes from the fact that it incorporates between stylistics and sociolinguistics, following Turner (1973) who clearly states that "stylistics is that part of linguistics, which concentrates on variation in the use of language, often, but not exclusively, with special attention to the most conscious and complex uses of language in literature" ( Turner, 1973, p. 7). It also interrelates between stylistics and discourse analysis, given the fact that speech is the core of discourse, and that any discourse study takes into consideration speech as a priority in the analysis. Thus, this approach is based on three disciplines, stylistics, sociolinguistics, and discourse analysis. In Pygmalion, this phenomenon is highly manifested and exemplified.

Across the history of stylistics and literary discourse analysis, there have been some important advances made in the linguistic analysis of style in literary texts, heralding a sort of stylistics realized by Bakhtin as "Sociological stylistics". Around 1935, Bakhtin wrote that "any stylistics capable of dealing with the distinctiveness of the novel as a genre must be a sociological stylistic" (Bakhtin, 1981, p. 300). Bakhtin introduced this type of stylistics as a counterpart to the classical or rhetorical version, which, according to Bakhtin, turned a deaf ear to the social life of language, to the social provenance of the 'voices' represented in the novel and distributed between authors, narrators and characters. One of the most important claims of Bakhtin is that Sassurean linguistics, by foregrounding la langue over le parole, and by placing the situated production of utterances outside the domain of linguistic science had little to say about how a novelistic style might resonate with social meanings. Many scholars were influenced by Bakhtin's insights, for example Page (1973), Fowler (1977, 1981, 1986) Herman (1994, 1995, 2001) and Buck (1995, 1996, 1997), Qadha (2013). Those scholars believe that they can gain a better 
understanding of the forms and functions of discourse in literary texts by attending to some sociolinguistic and discourse analytic research on style. This paper goes in this direction, emphasizing the importance of using concepts from neighboring disciplines in the stylistic analysis of literary discourse in general and literary dialogues in particular. With reference to Pygmalion, it is undoubtedly one of the most important literary works where linguistic diversity is highly represented and clearly manifested. In this work, Bernard Shaw shows a very great interest in linguistics more than any other work. Beardsmore (2008, p. 712) explicitly states that "nowhere in his creative writing does Shaw's interest in linguistic phenomena come explicitly to the fore than in Pygmalion". Shaw in this play introduces speech variation as a technique used to disclose some significant social aspects of his characters, particularly Eliza. Thus, the main objective of this paper is to show how Bernard Shaw has successfully used this technique to inform us about his characters, their social class, social status, level of education, etc. in an indirect way. It also attempts to raise some serious discussions about the possibility of treating literary language as a naturally spoken/written language. This agrees with Fowler (1966) who objects to the whole argument of making a distinction between literary and non-literary language, without denying the existence of literature. To Fowler "The form of utterances designated 'literary' is assumed to hold no special problems consequent upon the designation as literature-it is just linguistic form. This must not be misunderstood, interpreted as a denial of the existence of literature" (Fowler, 1966, p. 10). In terms of Fowler, literature is nothing more than a "social discourse" (1981). Later on, he introduces a new term called "linguistic criticism" (1986) in which he reemphasizes his opposition to the concept of literary vs non-literary language distinction, stressing that the "belief in an exclusive category 'literature' or 'literary language' is liable to prove a hindrance rather than a help" (Fowler, 1986, vol. v). Pratt (1977) agrees with Fowler's rejection of the idea of the literary vs non- literary language dichotomy, and clearly confirms that "A linguistic model that can describe and explain the use of language in non-literary situations should be able to account as well for how we understand language in literary contexts" (Pratt, 1977, vol. xii). Similarly, Verdonk and Weber (1995) adopt the same position, considering literature as "a complex social and cultural process" (1995, p. 2).

In this paper, the author will use Bernstein's theory in the analysis of the selected dialogues in Pygmalion. Basil Bernstein (1971) argues that the social class into which a speaker is born determines the variety of English available to the child. If he is born into a working-class family, for example, he will have access only to a "restricted" variety of English. On the other hand, the child of a middle or upper-class family will have access to one more variety of the language. that is an "elaborated" version of English. The two codes are learned not just through exposure to the dominant modes of discourse within the two types of family, but also as a result of the roles and the kinds of behavior and relationship found originally in the families. The two codes are more sociological than purely linguistic in origin.

The elaborated code user is supposed to be more mobile, less tied to his immediate communicative situation, more able to generalize, to symbolize, more distanced and ironic in the way he relates language to subject matters than someone who knows the restricted code only. On the contrary, the restricted code user is limited to the meanings implicit in the immediate communicative situation, and he articulates these allusively, using many pronouns and other pro-forms, such as "things", "do", "get", presupposing that his addressee will understand what he means. Furthermore, he lacks the coding structures for qualification and exact specification of meaning enjoyed by the elaborated code user. The elaborated code promotes mobility, individuality, authority; the restricted code blocks these kinds of socioeconomic advantages (Cf. Bernstein, 1971; Fowler, 1977). On the cognitive side, the elaborated code is claimed to give access to universalistic meanings, whereas the restricted code limits its users to situational aspects of immediate contexts.

\section{Method}

The method that will be followed by the author is primarily based on the qualitative approach. In other words, the author will select some dialogues between Eliza and other characters and start analyzing them, using Bernstein's principles. The analysis of the selected dialogues will take into account language variation as the main criterion of analysis. The selected dialogues will be treated as if they were spoken naturally in real conversations. The analysis will take into consideration phonology, syntax, pragmatics and sociolinguistics as the basic levels of analysis for conducting the study. Thus, the analysis will be conducted at the micro-linguistic and macro linguistic levels

\subsection{Micro-Linguistic Level}

With respect to the micro-linguistic level, the analysis will take into account phonology and syntax as the main criteria of analysis

\subsubsection{Phonological Perspectives}

At the phonological level, the author will focus on how Eliza produces sounds when talking to others in the 
selected dialogues. The analysis will occur at two stages, before and after getting trained by Prof. Higgins. In other words, the author will track Eliza's speech phonologically as a restricted code user, and then as an elaborated code speaker. The sounds produced by Eliza along with her pronunciation of words in both stages will be compared and analyzed.

\subsubsection{Syntactic Perspectives}

A similar analysis of Eliza's syntactic contribution will be carried out. The author will try to shed some light on Eliza's grammar in terms of Bernstein's codes. Clear examples that show Eliza's poor syntactic contribution will be carefully selected and analyzed by the author. Other examples that explicitly manifest Eliza's syntactic shift towards standard English will be found out then analyzed by the author. The analysis will be based on the common grammatical rules and structures of standard English, and that any violation of these rules will be counted as part of the restricted version of English at the syntactic level.

\subsection{Macro-Linguistic Level}

As for the macro-linguistic level, the analysis will be conducted from pragmatic and sociolinguistic perspectives.

\subsubsection{Pragmatic Perspectives}

At the pragmatic level the author will analyze Eliza's speech in terms of some common pragmatic theories, namely speech act theory, politeness theory, and Grice's conversational principles. The selected extracts will be carefully examined and analyzed. The author will draw the reader's attention to the effect of Eliza's utterances on the addressee in the light of the FTA concept (face threatening acts) (Brown \& Levinson, 1987). Additionally, Grice's cooperative principles will be used in the analysis of Eliza's utterances.

\subsubsection{Speech Act Theory}

This very well-known theory will be used in the analysis of Eliza's utterances at the pragmatic level. The idea whether this theory can be used for analyzing literary utterances or not is not our concern here because there was a long debate about this issue (Cf. Pratt, 1977; Searle, 1979). The proponents of this theory are Austin (1962) and Searle (1969). They claim that there are three types of acts, locutionary or propositional act, illocutionary act, and perlocutionary act. A locutionary act is the act of producing a recognizable grammatical utterance in the language. An illocutionary act, on the other hand, is what to do in saying something, i.e. the attempt to accomplish some communicative purposes, for example, warning, greeting, reminding, informing, and commanding are all distinct illocutionary acts. A perlocutionary act, Austin further proposes, is an act which normally produces certain consequential effects upon the feelings, thoughts, or actions of the audience, or of the speaker, or of other persons (Note 1).

\subsubsection{Politeness Theory}

The author will use Brown and Levinson's (1987) politeness theory in the analysis of Eliza's speech (Note 2). This theory is based upon the assumption that speakers in any given language do not just convey information through their language; rather they use their language to do things. They propose that participants in conversations actually construct and build a personal relationship through the dialogue they negotiate with each other. The concept of face occupies a central place in this theory. It is associated with acts that are usually performed by speakers in their conversational turns.

\subsubsection{Face Threatening Acts}

The concept of face acts will be utilized in the analysis of Eliza's speech. Brown and Levinson construct their interactional model around a model person (MP), one who, from the outset, in addition to demonstrating a command of the language and a rational capability for determining the means needed to accomplish end goals, possesses two basic, somehow conflicting, "face acts" (Brown \& Levinson, 1987, p. 61). The first is the negative face wants, that is the want to be free to act unimpeded by others and to have one's individual rights, possessions, and territories uninfringed upon (ibid. 61). The second is the positive face wants, that is the want of every member that his wants be desirable to at least some others. The concept of face is associated with acts that are usually performed by speakers in their conversational turns. These acts, which are inherently threatening to the speaker or hearer, became the principal unit of analysis in Brown and Levinson's model and are called "face-threatening acts", (FTAs) (ibid. 60).

\subsubsection{Sociolinguistic Perspectives}

Eliza's speech will also be analyzed from sociolinguistic perspectives. The researcher will shed some light on the styles that are selected by Eliza in addressing others. As we all know, sociolinguistics studies those types of variation, which result from the correlation between language and social factors, such as social stratification, role, 
age, sex, ethnicity, etc. This very fact will highly be utilized in the analysis of Eliza's speech styles in her conversational turns. In terms of Joos (1962), there are five styles, consultative, casual, intimate, formal, and frozen style. The analysis will show whether Eliza Doolittle is able to choose from these five types the most appropriate one or not in her conversations with others.

\section{Speech Analysis of Eliza Doolittle in Terms of Bernstein's Theory}

As we said earlier in this paper, the analysis of Eliza's speech will be conducted in two stages. The first stage will be devoted to Eliza's speech as a restricted code user, whereas the second one will discuss her speech as an elaborated code speaker.

\subsection{Eliza as a Restricted Code User}

Looking at Eliza speaking in the first act, one can easily notice that she speaks non-standard English that can hardly be understood and thus replied to. It is a real reflection of the social background of the girl, who was brought up in a low-class family and received poor education due to the tragic economic condition of her family. Her parole is highly affected by such difficult circumstances, for one's parole cannot be improved unless his/her educational input is incorporated with the social factors. In other words, the speaker should put what he learns into effect, and interact with the speech community he belongs to. It is called unconscious learning, as the speaker usually unconsciously does this linguistic behavior. Eliza exemplifies what may be called poor language performance in her dialogues with others. In her dialogue with Freddy, for example, Eliza speaks in this way "Nah then, Freddy: look wh' y' gowin, deah" (2). This utterance is apparently non-standard English used mostly by non-educated people. It is an example of restricted code at the syntactic and phonological levels. At the syntactic level, Eliza uses the above grammatical structure instead of the standard form, why are you going there? Thus, Eliza's speech is a clear deviation from the standard form of English. This kind of speech form may create ambiguity for the addressee who may not be able to understand what message she wants to convey. At the phonological level, she utters you, going, there, as y, gowin, and deah respectively. Freddy couldn't perceive what she has said, and thus couldn't respond to her question. He only says sorry, which is an indication of the difficulty he faces in understanding her utterances.

Similarly, in her dialogue with Freddy's mother, Eliza again speaks non-standard English that is full of vague and unclear utterances. She gives us a clear example of a girl whose linguistic performance indicates her social status and level of education: 'Ow, eez ye-ooa san, is e? Wal, fewd dan y' de-ooty bawmz a mather should, eed now bettern to spawl a pore gel's flahrzn than ran awy atbaht pyin. Will ye-oo py mef'them?" (9). These utterances are supposed to be an answer for Frdeddy's mother's question: "How do you know that my son's name is Freddy, pray?" (2) Thus, it is a clear example of what Bernstein calls restricted code. It can be easily noticed that the linguistic features of these utterances reveal many social aspects of Eliza. Bernard Shaw, it seems, doesn't want to tell us directly about the social background of his actress; instead, he prefers to use this linguistic technique to disclose the social and linguistic behavior of the flower girl. She, in this extract, fails to respond to Friddy's mother's question "How do you know that my son's name is Freddy, pray?" In terms of conversational principles and apart from her unintelligible dialect, Eliza's answer is not in an agreement with the question asked. It can be argued here that the restricted code users like Eliza usually fail to cope with the conversational stream and often provide poor performance in their conversational turns. This conversational failure usually causes conversational unpredictability to the addressee (Cf. Paterson et al., 2016) and raises uncertainty about the whole conversational atmosphere. He/she, as a result, cannot take his/her conversational turn properly and sometimes turns silent. The restricted code, it can be claimed, does not help Eliza to answer Freddy's mother's question. Even when she insists to get the answer, asking for the second time "Now tell me how you know the young gentleman's name?" (9), she fails to provide the answer, resorting to the assertive speech act of denial "I didn't." (9). Eliza, it seems, cannot find a suitable expression for answering this question, as the restricted code users do not usually think beyond the immediate situations, and in many occasions, they resort to closing the conversation when they fail to compete communicatively with the other conversational participant. In terms of Grice's cooperative principles (1975), Eliza violates the maxim of quality, which asserts that the speaker must be truthful and should not say what he/she believes to be false. It can be claimed here that the minimal cognitive content, which is a feature of the restricted code does not enable its users to give immediate answers to sudden questions.

With reference to the sociolinguistic perspectives, we find Eliza unable to select the most suitable style that is usually adopted when one speaks with strangers (Cf. Joos, 1962; Ervin Tripp, 2001). To Eliza, Freddy's mother is a stranger, conversing with her for the first time. Besides, she is superior to her in social status, age, and economic status. Therefore, it is inevitable to select a formal style, but she didn't. Her style is full of contracted forms, free from formal address forms (Cf. Hudson, 2003), full of face-threatening acts FTAs (Cf. Brown \& Levinson, 1987). 
All these features characterize the informal style that is usually selected when one addresses intimate and familiar interlocutors. In a nutshell, the flower girl in the above extracts appears as a poor interlocutor compared to her addressee. Both at the macro and micro-linguistic levels (Note 3), she was unable to indulge eloquent utterances, fluent expressions, and convincing argument. Thus, the overall impression about her language is quite disappointing and that Shaw could successfully present her as a lady whose language reveals who she is, to what class she belongs, and what type of education she has experienced.

\subsection{Eliza as an Elaborated Code User}

In this part of the paper, we will see how Eliza's language drastically changes as a result of education and language training. Prof. Higgins (Note 4), who attempts a social transformation for the underclass lady, believes that the first step towards achieving this fundamental social shift starts with language. To Higgins, Eliza's linguistic divergence from the norms of Standard English is the main reason for her social unacceptability. It is considered "a deep gulf" (Muggleston, 1993, p. 387) that separates the working class from upper-class people. Thus, Higgins' mission is to abolish this gulf between the two classes. Eliza herself realizes this obstacle, as she states "I want to talk like a lady" (18).

Having a look at Eliza's speech after being linguistically trained by Higgins, we will find a great improvement in her language performance, see, for example, this extract from her dialogue with Higgins:

Liza [much troubled] I want a little kindness. I know I'm a common ignorant girl, and you a book-learned gentleman; but I'm not dirt under your feet. What I done [correcting herself] what I did was not for the dresses and the taxis: I did it because we were pleasant together and I come - came - to care for you; not to want you to make love to me, and not forgetting the difference between us, but more friendly like (69). Thus, one can hardly believe that it is Eliza Doolittle speaking. There is absolutely no comparison between this conversational contribution and the previous ones. Eliza, it seems, has grown up socially and linguistically. Her language here is not different from anyone's belonging to the upper or middle-class family. Her speech above has the characteristics of the elaborated code version. No linguistic errors are seen, and when she commits an error, she immediately corrects herself. Her conversational turn is full of strong expressions which may give an indication of her self-confidence in front of her addressee. She appears to be in full control of language at all linguistic levels and goes beyond the ordinary use of language, a task that is only fulfilled by elaborated code speakers. At the phonological level, she produces sounds very clearly and her pronunciation is like any other speaker of standard English. At the syntactic level, she produces well-structured grammatical sentences that are normally produced by standard English speakers. At the sociolinguistic level, Eliza is able to select the most appropriate style that suits both, the communicative situation and the addressee, an art which she largely missed when she was a restricted code speaker.

In this extract, Eliza could successfully show her argumentative skill that is illustrated in using varied types of speech acts (declarative, assertive, accusative, direct, indirect). This technique enables the addresser to convey more than one single message in one conversational turn. Besides, the use of varied speech acts in a single conversational turn requires the existence of different illocutionary acts (the interpretation of the utterance by the addressee), which accordingly demand different perlocutionary acts (the verbal reaction of the addressee towards the illocutionary act). Thus, the addressee becomes scattered how to react to the addresser's different speech acts manifested in his utterances. He/she, as a result, loses control over the conversation and lets the other interlocutor lead its direction the way he wants. Eliza, in this conversational turn, shows a tremendous change in her speech style and proves that she is communicatively qualified to converse with whosoever, including her own teacher.

Let's take another example that proves the linguistic maturity of Eliza that can be taken as a sign of her social and communicative transition: It's not because you paid for my dresses. I know you are generous to everybody with money. But it was from you that I learnt really nice manners; and that is what makes one a lady, isn't it? You see it was so very difficult for me with the example of Professor Higgins always before me. I was brought up to be just like him, unable to control myself, and using bad language on the slightest provocation. And I should never have known that ladies and gentlemen didn't behave like that if you hadn't been there (63). It is really a rectified type of utterances. Eliza is able to express her inner feelings and thoughts in a very sophisticated manner. No one can predict this marvelous change in her speech. These types of utterances prove that Prof Higgins' efforts in changing her linguistic behavior have paid off. The extract proves that Eliza is able now to select words and utterances like educated people. Knowing the addressee's social and economic status (Higgins), she succeeds to pick up, out of different styles, the most appropriate one. The first utterance shows how she is able to use an expression that unwillingly involves the participant in attempting to guess what message the speaker wants exactly to convey. It is not because you paid for my dress, is a well-structured sentence, but there is something missing at 
the discourse level. The choice is given to the addressee to select anything among the different expressions available in the language to complete Eliza's utterance. It is really an extraordinary conversational technique that is only adopted by qualified communicators who have a strong command over their language. Only elaborated code users can single themselves out with such a powerful conversational style. Eliza, then, tries to save Higgin's face by using praising expressions that soften her verbal attack in the first utterance: "I know you are generous to everybody with money. But it was from you that I learnt really nice manners". It is thus obvious that the previously Cockney speaking lady is now able to use the standard form of English and select from which the most appropriate forms and expressions that harmonize with what Halliday and Hasan (1989) called field, mode, and tenor of discourse.

\section{Conclusion}

In this paper, we can conclude that Bernstein's restricted and elaborated codes were successfully presented by Bernard Shaw. He could cleverly use this sociolinguistic technique as a stylistic device to reveal many social aspects of Eliza Doolittle. It was clearly observed that the theory can be applied to literary texts, given the fact that any literary dialogue is a manifestation of a similar communicative situation taking place in the actual world (Fowler, 1977, 1981, 1986; Pratt, 1977; Buck, 1995; Buck \& Austin, 1997). The author could successfully track what can be called the "linguistic transition" of Eliza, from a poor colloquial cockney variety of English into a standard form or RP English.

It can be claimed here that Bernard Shaw didn't use this language technique arbitrarily. He rather wanted to convey a social message indirectly through the use of language. It was noticed that language can reveal many social aspects of the speaker (character) such as, his/her social class, socio-economic status, level of education, conversational performance, etc. Through the analysis of Eliza's speech, we came to know that there is an inevitable relationship between language performance and education. This relationship could easily be observed by comparing Eliza's language performance before and after being linguistically trained by Prof. Higgins.

The paper concluded that the use of language variation can be taken as a stylistic device to discover the social background of the characters, especially when the author avoids informing the reader directly about it. This study, hopefully, could succeed in presenting a new model of stylistics that is different from the traditional version, whose ultimate concern was only to find out the aesthetic aspects presented by writers in their work. This model of stylistics (socio-stylistics), hopefully, could answer many inquiries related to the role of stylistics in analyzing what can be called "characters' utterances" or "characters' speech". Thus, this model of stylistics provided by this paper might be counted as a new trend in the world of stylistics. With respect to the minimum unit of analysis, this type of stylistics exceeded the old version of stylistics whose ultimate goal was to analyze only the word as the minimum unit of stylistic analysis.

\section{References}

Austin, J. (1962). How to Do Things with Words. Oxford: Clarendon Press.

Bakhtin, M. M. (1981). Discourse in the Novel. In M. Holquist (Ed.), The Dialogic Imagination: Four Essays (trans. C. Emerson and M. Holquist, pp. 259-422). Austin: University of Texas Press.

Beardsmore, H. (2008). A Sociolinguistic Interpretation of Pygmalion. English Studies, 60(6), 712-719 https://doi.org/10.1080/00138387908598012

Bernstein, B. (1971). Class, Codes and Control (Vol. I). London: Routledge and Kegan Paul. https://doi.org/10.4324/9780203014035

Brown, P., \& Levinson, S. (1987). Politeness: Some Universal in Language Usage. Cambridge: Cambridge University Press. https://doi.org/10.1017/CBO9780511813085

Buck, R. (1996). Reading Forster's Style: Face Actions and Social Scripts in Maurice. Style, 30, 69-94.

Buck, R. (1997). Towards an Extended Theory of Face Action: Analyzing Dialogue in E.M. Forster's A Passage to India. Journal of Pragmatics, 27, 83-106. https://doi.org/10.1016/0378-2166(95)00068-2

Buck, R., \& Austin, T. (1995). Dialogue and Power in E.M. Forster's Howards End. In P. Verdonk \& J. Weber (Eds.), Twentieth Century Fiction: From Text to Context (pp. 63-77). London: Routledge.

Cap, P. (2010). Pragmatics, Micropragmatics, Macropragmatics. Lodz Papers in Pragmatics, 6(2), 195-228. https://doi.org/10.2478/v10016-010-0011-0

Edwards, J. (2009). Language and Identity: An Introduction. Cambridge: Cambridge University Press. https://doi.org/10.1017/CBO9780511809842 
Ervin, T. S. (2001). Variety, Style Shifting, and Ideology. In P. Eckert \& J. Rickford (Eds.), Style and Sociolinguistics Variation (pp. 44-56). Cambridge: Cambridge University Press. https://doi.org/10.1017/CBO9780511613258.003

Fowler. R. (1966). Linguistic Theory and the Study of Literature. In R. Fowler (Ed.), Essays on Style and Language: Linguistic and Critical Approaches to Literary Style (pp. 1-28). London: Routledge, and Kegan Paul.

Fowler, R. (1977). Linguistics and the Novel. London: Methuen.

Fowler, R. (1981). Literature as Social Discourse: The Practice of Linguistic Criticism. London: Batsford.

Fowler, R. (1986). Linguistic Criticism. Oxford: Oxford University Press.

Gazdar, G. (1981). Speech Act Assignment. In K. Aravind et al. (Eds.), Elements of Discourse Understanding (pp. 64-83). Cambridge: Cambridge University Press.

Grice, P. (1975). Logic and Conversation. In P. Cole \& J. Morgan (Eds.), Syntax and Semantics (Vol. III: Speech Acts, pp. 41-58). New York: Academic Press.

Halliday, M. K. A., \& Hassan, R. (1989). Language Context, and Text: Aspects of Language in a Social Semiotic Perspective. Oxford: Oxford University Press.

Herman, D. (1994). The Mutt and Jute Dialogue in Joyce's Finnegans Wake: Some Gricean Perspectives. Style, $28,219-241$.

Herman, D. (1995). University Grammar and Narration From. Durham, N. C: Duke University Press.

Herman, D. (2001). Style Shifting in Edith Wharton's the House of Mirth. Language and Literature, 10(1), 6177. https://doi.org/10.1177/0963-9470-20011001-04

Hudson, R. (2003). Sociolinguistics. Cambridge: Cambridge University Press.

Joos, M. (1962). The Five Clocks. Bloomington: Indiana University.

Katz, J. (1977). Propositional Structure and Illocutionary Force: A Study of the Contribution of Sentence Meaning to Speech Acts. New York: Crowell.

Mahmoud, R. (2016). Pragmatics between microlinguistic and macrolinguistic level of Analysis. Global Journal of Foreign Language Teaching, 6(3), 126-129. https://doi.org/10.18844/gjflt.v6i3.1659

Mugglestone, L. (1993). Shaw, Subjective Inequality, and the Social Meanings of Language in Pygmalion. RES New Series, XLIV(175), 373-385. Oxford: Oxford University Press. https://doi.org/10.1093/res/XLIV.175.373

Paterson, L, Coffey, L., \& Peplow, D. (2016). Negotiating Stance Within Discourse of Class: Reactions to Benefits Streets. Discourse Society, 27(2), 195-214. https://doi.org/10.1177/0957926515611558

Pratt, M. (1977). Toward A Speech Act Theory of Literary Discourse. Bloomington, IN: Indiana University Press.

Qadha, A (2003). How Pragmatics Leads to a Better Interpretation of Poetry: A Discourse-Stylistic Study of D.H. Lawrence's Poem "Sorrow". GSTF International Journal on Education, 1(2). https://doi.org/10.5176/2345-7163_1.2.32

Searle, J. (1969). Speech Acts: An Essay in the Philosophy of Language. Cambridge: Cambridge University Press. https://doi.org/10.1017/CBO9781139173438

Searle, J. (1979). Expressions and Meaning: Studies in the Theory of Speech Acts. Cambridge: Cambridge University Press. https://doi.org/10.1017/CBO9780511609213

Shaw, B. G. (1994 [1916]). Pygmalion. New York: Dover Publications Inc.

Turner, G. (1973). Stylistics. Harmondsworth: Penguin.

Verdonk, P., \& Weber, J. (1995). Twentieth Century Fiction from Text to Context (pp. 7-31). London and New York: Routledge. 


\section{Notes}

Note 1. For more details, see Austin, 1962, Searle, 1969, 1979, Katz, 1977, and Gazdar, 1981.

Note 2. Politeness theory relies heavily on speech act theory in analyzing the concept of FTAs.

Note 3. The microlinguistic levels refer to phonology and syntax, whereas the macro levels refer to pragmatics and sociolinguistics. With reference to pragmatics, some scholars classify it as a microlinguistic level and some others as macrolinguistic, for more details, however, see Cap (2010), and Mahomood (2016).

Note 4. Prof. Higgins is presented in the play as a professor of phonetics.

\section{Copyrights}

Copyright for this article is retained by the author, with first publication rights granted to the journal.

This is an open-access article distributed under the terms and conditions of the Creative Commons Attribution license (http://creativecommons.org/licenses/by/4.0/). 